\title{
Kesan Penggunaan Teknik Peer Instruction dengan Pendekatan Kelas Flipped terhadap Pencapaian Pemahaman Konsep Sejarah
}

\author{
The Effect of Using Peer Instruction Technique with Flipped Classroom Approach on \\ Historical Concept Understanding Performance
}

\author{
M.Kaviza \\ kavizakaviza@yahoo.com
}

\begin{abstract}
Abstrak
Kajian ini bertujuan untuk mengkaji kesan penggunaan teknik peer instruction dengan pendekatan kelas flipped terhadap pencapaian pemahaman konsep sejarah dalam kalangan murid Tingkatan Empat. Kajian ini merupakan kajian eksperimen dengan reka bentuk faktorial 2 X 2 yang melibatkan seramai 122 orang murid dari dua buah sekolah yang dikategorikan sebagai kumpulan eksperimen dan kumpulan kawalan. Ujian pencapaian pemahaman konsep sejarah yang dibina sendiri oleh pengkaji bagi topik Perkembangan di Eropah merupakan instrumen kajian ini yang telah disahkan oleh pakar penilai dan mempunyai nilai kebolehpercayaan, indeks kesukaran dan diskriminasi yang baik. Data kajian ini dianalisis secara deskriptif dan inferensi dengan menggunakan perisian IBM SPSS Statistics. Analisis inferensi yang digunakan adalah ujian-t Sampel Tak Bersandar dan ujian ANOVA Dua Hala. Dapatan kajian ini menunjukkan bahawa murid-murid dalam kumpulan eksperimen (pendekatan flipped dengan teknik peer instruction) dapat meningkatkan pencapaian pemahaman konsep sejarah yang lebih tinggi berbanding dengan murid-murid dalam kumpulan kawalan (pendekatan flipped tanpa teknik peer instruction). Di samping itu, murid berpencapaian tinggi dan rendah dalam kumpulan eksperimen menunjukkan peningkatan yang lebih baik berbanding dengan murid berpencapaian tinggi dan rendah dalam kumpulan kawalan. Terdapat kesan interaksi yang signifikan antara kaedah pengajaran dan tahap pencapaian murid terhadap min skor pencapaian pemahaman konsep sejarah. Kajian ini diharapkan dapat dijadikan sumber rujukan kepada guru sejarah dalam merancang kaedah pengajaran dan pembelajaran sejarah selaras dengan perkembangan teknologi maklumat yang canggih.
\end{abstract}

Kata Kunci: Murid berbeza tahap pencapaian, pendekatan kelas flipped, pencapaian, pemahaman, konsep sejarah, teknik peer instruction.

\section{Abstract}

The purpose of this study is to examine the effect of flipped classroom approach with using peer instruction technique on historical concept understanding performance among form four students. This is a quasi-experimental study using $2 \times 2$ factorial design with involving 122 students from two schools with categorized into experimental group and control group. Performance test on Europe Civilizations topic is instrument in this study which has been verified by the content expert and has a 
good reliability value, difficulty and discrimination index. The data were analysed using descriptive and inferential statistics using IBM SPSS Statistics computer programme. The inferential analysis used is independent sample t-test and two-way ANOVA test. The findings of this study indicate that students in experimental group (flipped classroom approach with using peer instruction technique) showed that higher enhance their historical concept understanding performance compared to students in control group (flipped classroom approach without using peer instruction). Besides that, the higher dan lower performances students in experimental group also showed higher score of historical concept understanding compared to control group in this study. There are the significant interaction effect of teaching method and different level of achievement student on the mean score of understanding historical concept. This study is expected as source of reference to history teachers in planning of teaching and learning methods in line with the development of information technology.

Keywords: Different level of achievement students, flipped classroom approach, historical concept understanding performance, peer instruction technique.

\section{PENGENALAN}

Perkembangan pesat dalam bidang teknologi telah membawa perubahan kepada sistem pendidikan sejarah dalam memenuhi tuntutan dan cabaran semasa. Teknologi memainkan peranan penting dalam mentransformasikan budaya belajar yang luwes di dalam bilik darjah (Abdul Rahim Abdul Rashid, 2000; Haydn, Arthur \& Hunt, 2001). Semenjak tahun 1990-an, penggunaan komputer dan internet telah membawa perubahan kepada keberkesanan proses pengajaran dan pembelajaran pada peringkat global (Heinich, Moleda, Russell \& Smaldino, 2002). Sistem pendidikan sejarah juga telah mengalami perubahan daripada pendekatan tradisional kepada pendekatan terkini yang melibatkan penggunaan komputer dan internet agar dapat membentuk murid yang aktif dan produktif (Mohamad Rossafri \& Toh, 2010). Semenjak tahun 2007, pendekatan kelas flipped telah mendapat perhatian dalam masyarakat pendidikan yang berdasarkan kepada peralihan daripada pemerolehan maklumat secara bersemuka di dalam kelas kepada pemerolehan maklumat atas talian (Rozinah Jamaludin \& Siti Zuraidah Md Osman, 2014).

Konsep flipped merupakan pendekatan dalam pengajaran dan pembelajaran yang memfokuskan kepada pembentukan persekitaran pembelajaran yang berpusatkan murid yang berbantukan teknologi dan aktiviti kolaborasi di dalam kelas (Westermann, 2014). Pendekatan kelas flipped telah membuat peralihan paradigma pembelajaran berpusatkan guru kepada kurikulum yang berlandaskan kepada keperluan untuk membimbing murid dalam proses pengajaran dan pembelajaran (Hamdan, Knight \& Arfstrom, 2013). Pendekatan pengajaran ini memudahkan murid untuk meneroka bahan-bahan pengajaran di luar kelas melalui pembacaan dan tontonan video kuliah dan menggunakan masa di dalam kelas untuk menguasai dan memahami kandungan bahan-bahan tersebut. Persekitaran pembelajaran baharu adalah lebih fleksibel yang dapat mewujudkan lebih peluang untuk berkolaborasi dengan meluas dalam proses pendidikan. Pendekatan kelas flipped dapat menyediakan murid lebih fleksibiliti dalam mengakses pelbagai maklumat mengikut keperluan agar mereka dapat membina 
persekitaran pembelajaran mereka sendiri. Jelaslah bahawa, pelaksanaan pendekatan kelas flipped dalam pendidikan sejarah dapat mewujudkan suasana pembelajaran yang lebih menarik (Westermann, 2014).

\section{PERNYATAAN MASALAH}

Murid-murid didapati masih kurang untuk memahami konsep-konsep sejarah dengan betul dengan memberikan penjelasan yang terperinci (Stoskopf \& Bermudez, 2008). Tambahan pula, pemahaman konsep sejarah yang rendah adalah berpunca daripada kelemahan murid menjawab soalan yang berkaitan dengan konsep-konsep sejarah dalam topik sejarah Eropah (Abdul Jaleel Abdul Hakeem; 2001; Khadijah Ahmed, 2002 \& Teo, 2007). Oleh itu, pemahaman konsep sejarah adalah sangat penting dalam proses pengajaran dan pembelajaran sejarah. Justeru, kajian ini bertujuan untuk mengkaji kesan pendekatan kelas flipped dengan teknik Peer Instruction terhadap pencapaian pemahaman konsep sejarah dalam kalangan murid Tingkatan Empat. Oleh itu, murid dalam kumpulan eksperimen merupakan murid yang mengikuti pengajaran berdasarkan pendekatan kelas flipped dengan teknik peer instruction, manakala murid dalam kumpulan kawalan pula merupakan murid yang mengikuti pengajaran berdasarkan pendekatan kelas flipped tanpa teknik peer instruction. Secara khususnya, objektif kajian ini adalah:

1. Mengenal pasti perbezaan skor min pencapaian pemahaman konsep sejarah bagi murid dalam kumpulan eksperimen berbanding dengan murid dalam kumpulan kawalan.

2. Mengenal pasti perbezaan skor min pencapaian pemahaman konsep sejarah bagi murid berpencapaian tinggi dalam kumpulan eksperimen berbanding dengan murid berpencapaian tinggi dalam kumpulan kawalan.

3. Mengenal pasti perbezaan skor min pencapaian pemahaman konsep sejarah bagi murid berpencapaian rendah dalam kumpulan eksperimen berbanding dengan murid berpencapaian rendah dalam kumpulan kawalan.

4. Mengenal pasti sama ada terdapat kesan interaksi antara kaedah pengajaran dan tahap pencapaian murid terhadap skor min pencapaian pemahaman konsep sejarah

\section{TINJAUAN LITERATUR KAJIAN}

\section{Pendekatan Kelas Flipped}

Menurut Mohamad Amin dan Ebrahim Panah (2014) telah mendefinisikan pendekatan kelas flipped sebagai konsep pedagogi yang menggantikan piawaian kuliah dan format kelas yang berpeluang mengkaji bahan-bahan pengajaran yang diperolehi di luar kelas. Pada dasarnya, istilah flipped dikenal pasti daripada konsep kelas biasa yang menjadi tempat menyampaikan pelajaran melalui beberapa format kuliah. Dalam persekitaran kelas biasa, murid diberikan tugasan kerja rumah untuk disiapkan di luar waktu sekolah mengikut kelapangan masa murid tersebut. Idea asas dalam pendekatan kelas 
flipped ialah penerimaan maklumat dilakukan di luar kelas secara akses kendiri, manakala masalah berkaitan dengan maklumat tersebut diselesaikan melalui aktiviti kolaborasi dengan rakan-rakan di dalam kelas (Lage, Platt, Tregilia, 2000).

Di samping itu, Gerstein, (2012) pula telah mendefinisikan pendekatan kelas flipped sebagai tempat untuk menyelesaikan masalah, memperolehi konsep baru dan menggalakkan pembelajaran kolaboratif dalam kalangan murid dengan menggabungkan unsur penglibatan interaktif dan penyepaduan antara kandungan maklumat yang diperolehi. Oleh itu, murid perlu menguasai maklumat melalui tontonan rakaman kuliah, podcast atau bahan bacaan lain di luar kelas (Baker, 2000). Hal ini berbeza dengan kaedah pengajaran konvensional yang membolehkan murid hanya menguasai maklumat di dalam kelas sepenuhnya.

\section{Pelaksanaan Pendekatan Kelas Flipped dalam Pendidikan Sejarah}

Terdapat beberapa kajian yang berkaitan dengan pelaksanaan pendekatan kelas flipped dalam pengajaran dan pembelajaran sejarah di luar negara. Antaranya, kajian Gaughan (2014) telah mengingtegrasikan pendekatan kelas flipped sebagai kaedah pedagogi utama dalam kursus sejarah di Universiti Colorado. Pendekatan ini dilaksanakan dengan menggunakan perisian Blackboard sebagai platform yang menyediakan pautan terhadap video, tugasan dan maklumat tambahan secara talian bagi membentuk pemahaman yang baik dan menggalakkan perbincangan yang relevan.

Seterusnya, Westermann (2014) pula telah mengkaji persepsi murid dan guru terhadap pelaksanaan pendekatan kelas flipped dalam pengajaran sejarah di Universiti Texas dengan menggunakan video rakaman bagi menggalakkan aktiviti kolaboratif semasa sesi pembelajaran bersemuka di dalam kelas dengan menyediakan ruang kepada murid untuk berkongsi pengalaman mereka dan membuka perbincangan yang meluas. Sungguhpun begitu, pelaksanaan pendekatan kelas flipped dalam mata pelajaran sejarah dilaksanakan tanpa memfokuskan aspek penglibatan aktif dan pemahaman konsep sejarah yang merupakan dua aspek penting yang perlu diberi perhatian. Perkara ini telah memberi cadangan untuk mengingtegrasikan penggunaan teknik Peer Instruction dengan pendekatan kelas flipped dalam pengajaran sejarah.

\section{Teknik Peer Instruction}

Crouch dan Mazur (2001) telah memperkenalkan kaedah pengajaran konstruktivis yang dikenali sebagai teknik peer instruction yang memfokuskan kepada aspek penglibatan interaktif (Mazur, 1997). Teknik peer instruction direka bentuk dengan tujuan mengingtegrasikan strategi pembelajaran kolaboratif yang dapat membantu murid untuk mengelakkan kekeliruan terhadap bahan-bahan pengajaran yang diberikan dengan serta merta (Mazur, 1997). Teknik peer instruction merupakan teknik pembelajaran aktif yang membolehkan murid belajar secara terarah kendiri dan aktif di dalam kelas dengan membincangkan jawapan dengan rakan-rakan lain (Duncan, 2005; Mazur, 1997; 
Sullivan, 2009).

Selain itu, teknik peer instruction juga membolehkan murid dapat menilai pemikiran mereka sendiri serta memberi maklum balas segera melalui penilaian formatif (VanDen et al, 2006; Burkholder, 2014). Oleh itu, murid perlu memahami konsep teras serta menerangkannya kepada rakan lain yang bermatlamat untuk menggalakkan interaksi antara murid-murid di dalam kelas dengan menekankan aspek pemahaman konseptual dan kemahiran penyelesaian masalah (Crouch \& Mazur, 2001; Dawn, 2009; Dean, 2013; Lasry et al, 2008). Sehubungan dengan itu, Mazur, (1997) telah menggunakan ujian diagnostik, soal selidik, kuiz, ujian konsep aneka pilihan dan ujian konseptual dalam mengingtegrasikan teknik peer instruction bagi mengukuhkan pemahaman konseptual dalam kalangan murid. Hal ini kerana keberkesanan pengingtegrasian teknik peer instruction di dalam kelas mempunyai kaitan dengan kualiti soalan yang dikemukakan berdasarkan kuantiti masa yang diberikan bagi menjawab dan berbincang jawapan tersebut sesama rakan-rakan yang lain (Draper \& Brown, 2004; Crouch \& Mazur, 2001; Mazur, 1997).

\section{METODOLOGI KAJIAN}

Kajian ini menggunakan pendekatan kuantitatif iaitu kaedah eksperimen kuasi dengan reka bentuk faktorial 2 X 2 (Cook \& Campbell, 1979) kerana melibatkan dua variabel tak bersandar yang dimanipulasikan iaitu kaedah pengajaran dan tahap pencapaian murid. Kajian ini melibatkan seramai 122 orang murid Tingkatan Empat dari dua buah sekolah menengah di utara Semenanjung Malaysia yang diwakili dengan tiga buah kelas intact class sebagai sampel kajian melalui teknik teknik persampelan bertujuan-rawak berstrata (Sandelowski, 2000). Sekolah yang dipilih terdiri daripada murid yang mempunyai latar belakang sosioekonomi yang sama, di samping pencapaian yang setara dalam mata pelajaran sejarah dalam peperiksaan Pentaksiran Tingkatan Tiga (PT3) pada tahun sebelumnya. Teknik persampelan bertujuan digunakan kerana pemilihan untuk mendapatkan murid dengan kriteria yang ditetapkan oleh pengkaji berdasarkan tujuan dan sasaran sampel, manakala teknik persampelan rawak berstrata pula digunakan untuk mendapatkan pembahagian subpopulasi yang seimbang (Othman Talib, 2013). Justeru, pengagihan murid berpencapaian tinggi (murid PT) dan murid berpencapaian rendah (murid PR) dilakukan berdasarkan keputusan peperiksaan Pentaksiran Tingkatan Tiga (PT3) pada tahun sebelumnya bagi mata pelajaran Sejarah yang diperolehi daripada Unit Peperiksaan Sekolah Menengah, Jabatan Pendidikan Negeri berkenaan seperti yang ditunjukkan pada Jadual 1 dan Jadual 2.

Jadual 1: Kriteria Pembahagian Murid Berdasarkan Tahap Pencapaian Murid

\begin{tabular}{cc}
\hline Murid & Kriteria \\
\hline Murid Pencapaian Tinggi (PT) & Gred A atau Gred B atau Gred C \\
\hline Murid Pencapaian Rendah (PR) & Gred D atau Gred E atau Gred F \\
\hline Sumber: Unit Peperiksaan Sekolah Menengah, Jabatan Pendidikan Negeri (2018)
\end{tabular}


Jadual 2: Bilangan Sampel Kajian

\begin{tabular}{ccc}
\hline & Kumpulan Eksperimen & Kumpulan Kawalan \\
\hline Murid PT & 30 & 31 \\
\hline Murid PR & 31 & 20 \\
\hline
\end{tabular}

Instrumen kajian yang digunakan ialah ujian pencapaian pemahaman konsep sejarah yang telah dibina oleh pengkaji sendiri bagi topik Perkembangan di Eropah yang berbentuk item objektif yang telah disahkan dari aspek kesahan kandungan oleh dua orang panel pakar penilai dalam bidang pendidikan sejarah yang berpengalaman luas melebihi 10 tahun serta mempunyai nilai kebolehpercayaan (KuderRichardson) sebanyak 0.916 yang dianggap baik berdasarkan interpretasi yang diberikan oleh Nunnally (1978). Ujian pencapaian ini didapati mempunyai nilai indeks kesukaran dan diskriminasi yang boleh diterima bagi tujuan kajian ini (Nitko, 2004). Data kajian ini dianalisis dengan menggunakan statistik deskriptif dan inferensi iaitu ujian-t Sampel Tak Bersandar dan ujian ANOVA Dua Hala yang dianalisis dengan menggunakan perisian IBM SPSS Statistics.

\section{DAPATAN KAJIAN}

\section{Objektif Kajian 1}

Bagi menjawab objektif kajian 1, pengkaji telah membentuk persoalan kajian (PK) dan hipotesis kajian nol $\left(\mathrm{H}_{\mathrm{o}}\right)$ untuk diuji pada aras kesignifikan $(p=0.05)$ seperti berikut:

PK1: Adakah terdapat perbezaan skor min pencapaian pemahaman konsep sejarah bagi murid dalam kumpulan eksperimen berbanding dengan murid dalam kumpulan kawalan?

$\mathrm{H}_{\mathrm{ol}}$ : Tidak terdapat perbezaan yang signifikan skor min ujian pasca pencapaian pemahaman konsep sejarah bagi murid dalam kumpulan eksperimen berbanding dengan murid dalam kumpulan kawalan.

Berdasarkan Jadual 3, skor min dalam ujian pasca pencapaian pemahaman konsep sejarah adalah lebih tinggi bagi murid dalam kumpulan eksperimen $(M=12.618, S D=3.675)$ berbanding dengan murid dalam kumpulan kawalan $M=11.344, S D=3.347)$. Berdasarkan keputusan ujian Levene's yang tidak signifikan $(F=0.951, p=0.331)$, keputusan ujian-t Sampel Tak Bersandar dalam Jadual 4 telah melaporkan bahawa terdapat perbezaan yang signifikan skor min dalam ujian pasca pencapaian pemahaman konsep sejarah $[t(120)=2.496, p=0.013]$ bagi murid dalam kumpulan eksperimen dan murid dalam kumpulan kawalan. Justeru, $\mathrm{H}_{\mathrm{o} 1}$ berjaya ditolak. Maka, dapat disimpulkan bahawa skor min pencapaian pemahaman konsep sejarah adalah lebih tinggi bagi murid dalam kumpulan eksperimen (pendekatan kelas flipped dengan teknik peer instruction) berbanding dengan murid dalam kumpulan kawalan (pendekatan kelas flipped). 
Jadual 3: Kriteria Pembahagian Murid Berdasarkan Tahap Pencapaian Murid

\begin{tabular}{lcccccc}
\hline & \multicolumn{3}{c}{ Kumpulan Eksperimen } & \multicolumn{2}{c}{ Kumpulan Kawalan } \\
\cline { 2 - 7 } & Ujian Pra & Ujian Pasca & $\begin{array}{c}\text { Perbezaan } \\
\text { Skor Min }\end{array}$ & Ujian Pra & Ujian Pasca & $\begin{array}{c}\text { Perbezaan } \\
\text { Skor Min }\end{array}$ \\
\hline Min & 10.423 & 12.618 & -2.195 & 10.473 & 11.344 & -0.871 \\
\hline Sisihan piawai & 3.118 & 3.675 & -0.557 & 3.325 & 3.347 & -0.022 \\
\hline
\end{tabular}

Jadual 4: Ujian-t Sampel Tak Bersandar bagi Perbezaan Skor Min Pencapaian Pemahaman Konsep Sejarah untuk Kumpulan Eksperimen dan Kumpulan Kawalan

\begin{tabular}{cccccccccc}
\hline & \multicolumn{1}{c}{} & & \multicolumn{5}{c}{ Ujian-t bagi persamaan min } \\
\cline { 2 - 9 } & Ujian Levene's & $\mathrm{t}$ & $\mathrm{df}$ & $\mathrm{p}$ & $\begin{array}{c}\text { Perbezaan } \\
\text { min }\end{array}$ & $\begin{array}{c}\text { Min ralat } \\
\text { Piawai }\end{array}$ & $\begin{array}{c}\text { 99\% selang keyakinan } \\
\text { bagi perbezaan }\end{array}$ \\
\cline { 2 - 9 } & $\mathrm{F}$ & Sig. & & & & & & Bawah & atas \\
\hline $\begin{array}{c}\text { Perbezaan } \\
\text { Skor Min }\end{array}$ & 0.951 & 0.331 & 2.496 & 120 & 0.013 & 1.274 & 0.511 & 0.267 & 2.281 \\
\hline
\end{tabular}

\section{Objektif Kajian 2}

Bagi menjawab objektif kajian 2, pengkaji telah membentuk persoalan kajian (PK) dan hipotesis kajian nol $\left(\mathrm{H}_{\mathrm{o}}\right)$ untuk diuji pada aras kesignifikan $(p=0.05)$ seperti berikut:

PK2: Adakah terdapat perbezaan skor min pencapaian pemahaman konsep sejarah bagi murid berpencapaian tinggi dalam kumpulan eksperimen berbanding dengan murid berpencapaian tinggi dalam kumpulan kawalan?

$\mathrm{H}_{02}$ : Tidak terdapat perbezaan yang signifikan skor min ujian pasca pencapaian pemahaman konsep sejarah bagi murid berpencapaian tinggi dalam kumpulan eksperimen berbanding dengan murid berpencapaian tinggi dalam kumpulan kawalan.

Berdasarkan Jadual 5, skor min dalam ujian pasca pencapaian pemahaman konsep sejarah adalah lebih tinggi bagi murid berpencapaian tinggi dalam kumpulan eksperimen $(M=15.967, S D=3.124)$ berbanding dengan murid berpencapaian tinggi dalam kumpulan kawalan $(M=13.129, S D=3.324)$. Berdasarkan keputusan ujian Levene's yang tidak signifikan $(F=0.238, \mathrm{p}=0.627)$, keputusan ujian-t Sampel Tak Bersandar dalam Jadual 6 telah melaporkan bahawa terdapat perbezaan yang signifikan skor min dalam ujian pasca pencapaian pemahaman konsep sejarah $[t(59)=3.433, \mathrm{p}=0.001]$ bagi murid berpencapaian tinggi dalam kumpulan eksperimen dan murid berpencapaian tinggi dalam kumpulan kawalan. Justeru, $\mathrm{H}_{02}$ berjaya ditolak. Maka, dapat disimpulkan bahawa skor min pencapaian pemahaman konsep sejarah adalah lebih tinggi bagi murid berpencapaian tinggi dalam kumpulan eksperimen (pendekatan kelas flipped dengan teknik peer instruction) berbanding dengan murid berpencapaian tinggi dalam kumpulan kawalan (pendekatan kelas flipped). 
Jadual 5: Perbezaan Skor Min Pencapaian Pemahaman Konsep Sejarah antara Kumpulan Eksperimen dan Kumpulan Kawalan (Murid Berpencapaian Tinggi)

\begin{tabular}{lcccccc}
\hline & \multicolumn{3}{c}{ Kumpulan Eksperimen } & \multicolumn{2}{c}{ Kumpulan Kawalan } \\
\cline { 2 - 7 } & Ujian Pra & Ujian Pasca & $\begin{array}{c}\text { Perbezaan } \\
\text { Skor Min }\end{array}$ & Ujian Pra & Ujian Pasca & $\begin{array}{c}\text { Perbezaan } \\
\text { Skor Min }\end{array}$ \\
\hline Min & 11.900 & 15.967 & -4.067 & 12.032 & 13.129 & -1.097 \\
\hline Sisihan piawai & 2.857 & 3.124 & -0.267 & 3.411 & 3.324 & 0.087 \\
\hline
\end{tabular}

Jadual 6: Ujian-t Sampel Tak Bersandar bagi Perbezaan Skor Min Pencapaian Pemahaman Konsep Sejarah untuk Kumpulan Eksperimen dan Kumpulan Kawalan (Murid Berpencapaian Tinggi)

\begin{tabular}{cccccccccc}
\hline & \multicolumn{1}{c}{} & \multicolumn{1}{c}{ Ujian-t bagi persamaan min } \\
\cline { 2 - 9 } & Ujian Levene's & $\mathrm{t}$ & $\mathrm{df}$ & $\mathrm{p}$ & $\begin{array}{c}\text { Perbezaan } \\
\text { min }\end{array}$ & $\begin{array}{c}\text { Min ralat } \\
\text { Piawai }\end{array}$ & $\begin{array}{c}\text { 99\% selang keyakinan } \\
\text { bagi perbezaan }\end{array}$ \\
\cline { 2 - 9 } & $\mathrm{F}$ & Sig. & & & & & 0.827 & 1.184 & 4.491 \\
\hline $\begin{array}{c}\text { Perbezaan } \\
\text { Skor Min }\end{array}$ & 0.238 & 0.627 & 3.433 & 59 & 0.001 & 2.838 & & \\
\hline
\end{tabular}

\section{Objektif Kajian 3}

Bagi menjawab objektif kajian 3, pengkaji telah membentuk persoalan kajian (PK) dan hipotesis kajian nol $\left(\mathrm{H}_{\mathrm{o}}\right)$ untuk diuji pada aras kesignifikan $(\mathrm{p}=0.05)$ seperti berikut:

PK3: Adakah terdapat perbezaan skor min pencapaian pemahaman konsep sejarah bagi murid berpencapaian rendah dalam kumpulan eksperimen berbanding dengan murid berpencapaian rendah dalam kumpulan kawalan?

$\mathrm{H}_{03}$ : Tidak terdapat perbezaan yang signifikan skor min ujian pasca pencapaian pemahaman konsep sejarah bagi murid berpencapaiaaan rendah dalam kumpulan eksperimen berbanding dengan murid berpencapaian rendah dalam kumpulan kawalan.

Berdasarkan Jadual 7, skor min ujian dalam pasca pencapaian pemahaman konsep sejarah adalah lebih tinggi bagi murid berpencapaian rendah dalam kumpulan eksperimen $(M=10.194, S D=2.151)$ berbanding dengan murid berpencapaian rendah dalam kumpulan kawalan $(M=9.700, S D=2.793)$. Berdasarkan keputusan ujian Levene's yang tidak signifikan $(F=2.381, p=0.128)$, keputusan ujian-t Sampel Tak Bersandar dalam Jadual 8 telah melaporkan bahawa terdapat perbezaan yang signifikan skor min ujian pasca dalam pencapaian pemahaman konsep sejarah $[t(59)=0.775, p=0.000]$ bagi murid berpencapaian rendah dalam kumpulan eksperimen dan murid berpencapaian rendah dalam kumpulan kawalan. Justeru, $\mathrm{H}_{03}$ berjaya ditolak. Maka, dapat disimpulkan bahawa skor min pencapaian pemahaman konsep sejarah adalah lebih tinggi bagi murid berpencapaian rendah dalam kumpulan eksperimen (pendekatan kelas flipped dengan teknik peer instruction) berbanding dengan murid brpencapaian rendah dalam kumpulan kawalan (pendekatan kelas flipped). 
Jadual 7: Perbezaan Skor Min Pencapaian Pemahaman Konsep Sejarah antara Kumpulan Eksperimen dan Kumpulan Kawalan (Murid Berpencapaian Rendah)

\begin{tabular}{lcccccc}
\hline & \multicolumn{3}{c}{ Kumpulan Eksperimen } & \multicolumn{2}{c}{ Kumpulan Kawalan } \\
\cline { 2 - 7 } & Ujian Pra & Ujian Pasca & $\begin{array}{c}\text { Perbezaan } \\
\text { Skor Min }\end{array}$ & Ujian Pra & Ujian Pasca & $\begin{array}{c}\text { Perbezaan } \\
\text { Skor Min }\end{array}$ \\
\hline Min & 9.065 & 10.194 & -1.129 & 8.967 & 9.700 & -0.733 \\
\hline Sisihan piawai & 2.351 & 2.151 & -0.200 & 3.157 & 2.793 & 0.364 \\
\hline
\end{tabular}

Jadual 8: Ujian-t Sampel Tak Bersandar bagi Perbezaan Skor Min Pencapaian Pemahaman Konsep Sejarah untuk Kumpulan Eksperimen dan Kumpulan Kawalan (Murid Berpencapaian Rendah)

\begin{tabular}{|c|c|c|c|c|c|c|c|c|c|}
\hline & & & \multicolumn{7}{|c|}{ Ujian-t bagi persamaan min } \\
\hline & \multicolumn{2}{|c|}{ Ujian Levene's } & $\mathrm{t}$ & df & $\mathrm{p}$ & $\begin{array}{c}\text { Perbezaan } \\
\text { min }\end{array}$ & $\begin{array}{c}\text { Min ralat } \\
\text { Piawai }\end{array}$ & $\begin{array}{r}99 \% \text { se } \\
\text { bag }\end{array}$ & $\begin{array}{l}\text { eyakinan } \\
\text { ezaan }\end{array}$ \\
\hline & $\mathrm{F}$ & Sig. & & & & & & Bawah & atas \\
\hline $\begin{array}{c}\text { Perbezaan } \\
\text { Skor Min }\end{array}$ & 2.381 & 0.128 & 0.775 & 59 & 0.000 & 0.494 & 0.637 & -0.781 & 1.768 \\
\hline
\end{tabular}

\section{Objektif Kajian 3}

Bagi menjawab objektif kajian 4, pengkaji telah membentuk persoalan kajian (PK) dan hipotesis kajian nol $\left(\mathrm{H}_{\mathrm{o}}\right)$ untuk diuji pada aras kesignifikan $(p=0.05)$ seperti berikut:

PK4: Adakah terdapat kesan interaksi antara kaedah pengajaran dan tahap pencapaian murid terhadap skor min pencapaian pemahaman konsep sejarah?

$\mathrm{H}_{04}$ : Tidak terdapat kesan interaksi yang signifikan antara kaedah pengajaran dan tahap pencapaian murid terhadap skor min pencapaian pemahaman konsep sejarah.

Dalam analisis statistik deskriptif pada Jadual 3, Jadual 5 dan Jadual 7 telah menunjukkan bahawa skor min dalam ujian pasca adalah lebih tinggi daripada ujian pra bagi skor min pencapaian pemahaman konsep sejarah dalam kumpulan eksperimen berbanding dengan kumpulan kawalan, di samping skor min dalam ujian pasca pencapaian pemahaman konsep sejarah adalah lebih tinggi bagi murid berpencapaian tinggi berbanding dengan murid berpencapaian rendah. Berdasarkan keputusan ujian Levene's yang tidak signifikan $(F(4,118)=0.951, p=0.331)$ pada Jadual 9 , keputusan ujian ANOVA Dua Hala pada Jadual 10 yang dijalankan menunjukkan bahawa terdapat kesan utama tahap pencapaian murid $\left[F(1,118)=13.138, p=0.001, \eta^{2}=0.929\right]$ dan kesan utama kaedah pengajaran $[F(1$, $\left.118)=3.467, p=0.004, \eta^{2}=0.634\right]$ adalah signifikan terhadap skor min pencapaian pemahaman konsep sejarah. Seterusnya, terdapat kesan interaksi yang signifikan antara kaedah pengajaran dan tahap pencapaian murid terhadap skor min pencapaian pemahaman konsep sejarah $[F(2,118)=2.902$, $\left.p=0.007, \eta^{2}=0.031\right]$. Justeru, $\mathrm{H}_{04}$ berjaya ditolak. Maka, terdapat kesan interaksi yang signifikan antara kaedah pengajaran dan tahap pencapaian murid terhadap skor min pencapaian pemahaman konsep sejarah. Oleh itu, dapat dirumuskan bahawa kaedah pengajaran dan tahap pencapaian murid adalah 
saling bersandar antara satu sama lain dalam mempengaruhi skor min pencapaian pemahaman konsep sejarah.

Jadual 9: Ujian Levene's Kesetaraan Varians bagi Skor Min Pencapaian Pemahaman Konsep Sejarah

\begin{tabular}{cccc}
\hline$F$ & $d f 1$ & $d f 2$ & Sig \\
\hline 0.951 & 4 & 118 & 0.331 \\
\hline
\end{tabular}

Jadual 10: Keputusan Ujian Kesan Variabel Antara Subjek

\begin{tabular}{lcccccc}
\hline Sumber & $\begin{array}{c}\text { Jumlah } \\
\text { Kuasa Dua } \\
\text { Jenis III }\end{array}$ & $\begin{array}{c}\text { Darjah } \\
\text { Kebebasan }\end{array}$ & $\begin{array}{c}\text { Min Kuasa } \\
\text { Dua }\end{array}$ & F & Sig & $\begin{array}{c}\text { Separa Eta } \\
\text { Kuasa Dua }\end{array}$ \\
\hline Pintasan & 27301.087 & 1 & 27301.087 & 310.190 & 0.006 & 0.997 \\
\hline MURID & 667.521 & 1 & 333.760 & 13.138 & 0.001 & 0.929 \\
\hline KAEDAH & 88.014 & 1 & 88.014 & 3.467 & 0.004 & 0.634 \\
\hline MURID*KAEDAH & 50.809 & 2 & 25.405 & 2.902 & 0.007 & 0.031 \\
\hline Ralat & 1670.558 & 118 & 8.753 & & & \\
\hline Pata
\end{tabular}

Pada aras kesignifikan 0.05

\section{PERBINCANGAN KAJIAN}

Dapatan kajian ini mendapati bahawa skor min pencapaian pemahaman konsep sejarah dalam kumpulan eksperimen secara signifikan adalah lebih tinggi daripada skor min pencapaian pemahaman konsep sejarah dalam kumpulan kawalan. Hal ini menunjukkan bahawa rawatan teknik peer instruction telah memberi kesan yang signifikan dalam meningkatkan pencapaian pemahaman konsep sejarah. Dapatan ini disokong oleh perbezaan skor min dalam ujian pasca pencapaian pemahaman konsep sejarah yang signifikan dalam kumpulan eksperimen dan kesan utama yang signifikan bagi jenis rawatan terhadap skor min pencapaian pemahaman konsep sejarah. Dalam kajian ini telah mencadangkan bahawa penggunaan teknik peer instruction dapat membantu murid mempelajari konsep sejarah berkaitan dengan topik Perkembangan di Eropah secara berkesan menerusi pendekatan kelas flipped. Dapatan kajian ini adalah selari dengan dapatan kajian-kajian terdahulu yang menunjukkan bahawa kepentingan murid sejarah yang dibantu dengan teknik peer instruction bagi membolehkan proses pembelajaran sejarah dilaksanakan secara berkesan (Haydn et al, 2001; Crouch \& Mazur, 2001). Sebagai pembelajar yang efektif, murid sejarah terlebih dahulu mempunyai pengetahuan sedia ada tentang kemahiran-kemahiran yang diperlukan untuk melaksanakan strategi pembelajaran secara berkesan. Apabila teknik peer instruction digunakan, murid sejarah dibekalkan dengan maklumat tentang penggunaan ujian konsep, kad jawapan, bahan pengajaran seperti video untuk ditonton di rumah yang diperlukan untuk menjalani pendekatan kelas flipped tersebut. Barton (2005), Tracy (2013) dan Mazur (1997) di dalam kajiannya mendapati bahawa dengan membimbing murid membuat perbandingan antara konsep-konsep sejarah, maka murid tersebut dapat memahami secara lebih mendalam tentang konsep-konsep sejarah berkenaan. 
Dapatan kajian ini mendapati bahawa terdapat kesan interaksi antara kumpulan pendekatan kelas flipped dengan teknik peer instruction dan pendekatan kelas flipped tanpa teknik peer instruction dengan tahap pencapaian murid terhadap skor min pencapaian pemahaman konsep sejarah. Hal ini menunjukkan bahawa rawatan teknik peer instruction memberi kesan interaksi yang signifikan dalam meningkatkan pencapaian pemahaman konsep sejarah berdasarkan tahap pencapaian murid. Dapatan ini disokong oleh perbezaan skor min yang signifikan yang diperolehi daripada pasangan kumpulan murid berpencapaian tinggi yang lebih tinggi pencapaian pemahaman konsep sejarah berbanding dengan murid berpencapaian rendah dalam kumpulan eksperimen dan kumpulan kawalan dan kesan utama yang signifikan bagi kumpulan rawatan terhadap skor min pencapaian pemahaman konsep sejarah. Justeru, dapatan ini mencadangkan bahawa pendekatan dalam kumpulan eksperimen dan kawalan mempunyai mekanisme yang berbeza dalam mendatangkan kesan yang signifikan terhadap peningkatan pencapaian pemahaman konsep sejarah dalam topik Perkembangan di Eropah. Berasaskan dapatan kajian yang menunjukkan bahawa penggunaan teknik peer instruction dengan pendekatan kelas flipped dapat meningkatkan pencapaian pemahaman konsep sejarah, maka dapatan ini adalah konsisten dengan kajian Harris \& Rea, (2006) yang turut mendapati rawatan yang berkesan dalam meningkatkan pencapaian pemahaman konsep sejarah. Dapatan ini juga adalah selari dengan dapatan kajian terdahulu yang dibuat oleh Counsel, (2000), Rao \& Dicarlo, (2002), dan Savinainen \& Scout, (2002) yang mendapati bahawa elemen teknik pembelajaran aktif membolehkan murid menjadi lebih peka terhadap pemahaman konsep sejarah mereka.

\section{KESIMPULAN}

Kajian ini menunjukkan bahawa penggunaan teknik peer instruction dengan pendekatan kelas flipped telah memberi impak yang berbeza terhadap pembelajaran berdasarkan tahap pencapaian murid. Teknik peer instruction dengan pendekatan kelas flipped didapati berkesan untuk meningkatkan pencapaian pemahaman konsep sejarah berdasarkan tahap pencapaian murid. Namun begitu, pendekatan kelas flipped tanpa teknik peer instruction juga berupaya meningkatkan pencapaian pemahaman konsep sejarah yang dilaporkan memberi kesan secara langsung dalam membantu murid berdasarkan tahap pencapaian murid untuk menggunakan kemahiran berfikir aras tinggi yang diperlukan secara sistematik. Implikasi dapatan kajian ini mencadangkan bahawa penggunaan teknik peer instruction dengan pendekatan kelas flipped memainkan peranan penting dalam memastikan murid berbeza tahap pencapaian berupaya untuk menjalani langkah-langkah teknik peer instruction secara berkesan. Kajian ini memberi sumbangan secara empirikal tentang kesan penggunaan teknik peer instruction yang boleh digunakan oleh guru bagi membantu murid melaksanakan pendekatan kelas flipped, namun begitu, murid masih boleh mengekalkan autonomi mereka dalam pembelajaran mereka (Siti Hajar Halili \& Zamzani Zainuddin, 2015; Raihanah, 2014). 
Kesan Penggunaan Teknik Peer Instruction dengan Pendekatan Kelas Flipped terhadap Pencapaian Pemahaman Konsep Sejarah Received Date: 26 July 2018; Accepted Date: 4 November 2018

\section{RUJUKAN}

Abdul Jaleel Abdul Hakeem (2001). Kefahaman Konsep Sejarah Di Kalangan Pelajar Tingkatan Lima. Tesis Sarjana: Universiti Kebangsaan Malaysia.

Abdul Rahim Abdul Rashid (2000). Panduan Latihan Mengajar. Kuala Lumpur: Dewan Bahasa dan Pustaka.

Baker, J.W. (2000). The Classroom Flip: Using Web Ccourse Management Tools to Become the Guide by the Side. In proceedings of the 11th International Conference on College Teaching and Learning. 9-17.

Barton, K. C. (2005). Teaching History. Primary Sources in History Breaking Through the Myths. Phi Delta Kappan, 86, 745753.

Burkholder, P. (2014). A Content Means to A Critical Thinking End: Group Quizzing In History Surveys. Journal the History Teacher, 47(4).

Cook, T. D. \& Campbell, D.T. (1979). Quasi-Experimentation: Design and Analysis Issues for Field Settings. Chicago: Rand Mcnally.

Counsel, C. (2000). Historical Knowledge and Historical Skills: A Distracting Dichotomy. Issues in History Teaching. London: Routledge. 54-71.

Crouch, C. H. \& Mazur, E. (2001). Peer Instruction: Ten Years of Experience and Result. American Journal of Physiology, 69(9), 970-977.

Dean, D. (2013). The Clicker Challenge: Using a Reader Response System in The British History Classroom. Journal the History Teacher, 46(3).

Draper, S. \& Brown, M.I. (2004). Increasing Interactivity in Lectures Using an Electronic Voting System. Journal of Computer Assisted, 20, 81-94.

Duncan, D. (2005). Clickers in the Classroom: How to Enhance Science Teaching Using Classroom Response Systems. San Francisco: Pearson Education.

Gaughan, J. E. (2014). The Flipped Classroom in World History. Journal the History Teacher, 47(2), 221-244.

Gerstein, J. (2012). Flipped Classroom: The Full Picture for Higher Education. Education Blog. Retrieved from: http://usergeneratededucation.Wordpress.Com/2012/05/15/Flipped-Classroom-The -Full-Picture-For-Higher-Education/

Hamdan, N. McKnight, P., McKnight, K., \& Arfstrom, K. (2013). A Review of Flipped Learning. Retrieved from http://www.flippedlearning.org/review.

Harris, R. \& Rea, A. (2006). Making History Meaningful: Helping Pupils See Why History Matters. Teaching History. London.

Haydn, T., Arthur, J., \& Hunt, M. (2001). Learning to Teach History in the Secondary School: A Companion to School Experience. London: Routledge Falmer.

Heinich, R, Molenda, Russel, J.D., \& Smaldino, S.E (2002). Instructional Media \& Technologies for Learning. Ohio Merill Prentice Hall.

Khadijah Ahmad. (2002). Tahap Pemahaman Konsep Dalam Penjanaan Sejarah Di Kalangan Pelajar Tingkatan Empat SMK Putrajaya. Tesis Sarjana: Universiti Kebangsaan Malaysia.

Lage, M.J., Platt, G.J., \& Treglia, M (2000). Inverting the Classroom: A Gateway to creating an inclusive learning environment. The Journal of Economic Education, 32(1), 30-43.

Lasry, N., Mazur, E., \& Watkins, J. (2008). Peer Instruction: From Harvard to the Two Years College. American Journal of Physics, 6, 1066-1069.

Mazur, E. (1997). Peer Instruction: A User's Manual. New Jersey: Prentice Hall.

Mohamad Rossafri \& Toh S. C. (2010). An Adaptive Multimedia Courseware for the Students' Different Cognitive Styles: A Pilot Study for History Subject. Procedia Computer Science, 3, 301-306.

Mohamed Amin Embi \& Ebrahim Panah (2014). Overview of Flipped Learning. Centre for Teaching \& Learning Technologies Bangi: UKM.

Nitko, A. J. (2004). Educational Assessment of Students. Upper Saddle River, NJ: Merril.

Nunnally, J. C. (1975). The Study of Change Evaluation Research: Principles Conserning Measurement Experimental Design and Analysis. In. Struening, E. L. \& Guttentag, M. (Pynt.). Handbook of Evaluation Research. Beverly Hills: Sage.

Othman Talib. (2013). Asas Penulisan Tesis Penyelidikan \& Statistik. Serdang: Penerbit UPM.

Raihanah. M. M. (2014). Flipped Classroom \& Meaningful Learning Among UKM Graduate Students: A Teacher's Reflection. Centre for Teaching \& Learning Technologies: UKM.

Rao, S. P. \& Dicarlo, S E. (2000). Peer Instruction Improves Performance on Quizzes. Advances in Physiology Education, 24(1), 51-55.

Rozinah Jamaludin \& Siti Zuraidah Md Osman (2014). The Use of A Flipped Classroom To Enhance Engagement And Promote Active Learning. Journal of Education and Practice, 5.

Sandelowski, M. (2000). Combining Qualitative and Quantitative Sampling, Data Collection Analysis Techniques in Mixed Methods Studies. Research in Nursing and Health 23: 246-255. 
Savinainen, A. \& Scout, P. (2002). The Force Concept Inventory: A Tool for Monitoring Student Learning. Physics Education, 37(1). 45-52.

Siti Hajar Halili \& Zamzami Zainuddin (2015). Enhancing Collaborative Learning in Flipped Classroom. Australian Journal of Basic and Applied Science, 9 (7).

Stoskopf, A. \& Bermudez, A. (2008). New Insights into How Students Learn About The Past: The Pedadogical Triangle Of Historical Understanding. Boston: Northeastern University.

Sullivan, R. (2009). Principles for Constructing Good Clicker Questions: Going Beyond Rote Learning and Stimulating Active Engagement with Course Content. Journal of Educational Technology Systems, 37(3), 335-347.

Teo Anak Juin (2006). Keberkesanan Pengajaran Perbandingan Konsep Dalam Pembelajaran Konsep Sejarah: Perbandingan Antara Aliran Sains Dan Aliran Sastera. Tesis Sarjana: Universiti Malaysia Sabah.

Tracy, M. H. A (2012). The Impact of Classroom Performance System Based Instruction with Peer Instruction upon Student Achievement and Motivation in Eighth Grade Math Students. Proquest.Digital Dissertations.

VanDen, B. I., Admiral, W., \& Pilot, A. (2006). Design Principles and Outcome of Peer Assessment in Higher Education. Studies in Higher Education, 31, 341-356.

Westermann, E. D. (2014). A Half-Flipped Classroom or An Alternative Approach? Primary Sources and Blended Learning. Journal Educational Research Quarterly, 38(2). 